\title{
Cysteine-Thiolato Dioxomolybdenum(VI) Species Supported by Water Soluble Poly(ethylene glycol) as a Molybdo-Oxidase Model. Its Enhanced Oxidative Ability in Water as Shown by the CD Spectral Investigation
}

\author{
Norikazu Ueyama, Etsuo Kamada, and Akira NAKAmUrA* \\ Department of Macromolecular Science, Faculty of Science, \\ Osaka University, Toyonaka, Osaka 560, Japan
}

(Received January 31, 1983)

\begin{abstract}
Water-soluble $\mathrm{MoO}_{2}$ (cys-O-PEG) ${ }_{2}$ as a model for molybdo-oxidases was prepared from $t$-butyloxycarbonyl-L-cysteine $\left(S\right.$-acetamidomethyl)- $\mathrm{O}-\left(\mathrm{CH}_{2} \mathrm{CH}_{2} \mathrm{O}\right)_{n} \mathrm{OH} \quad(t$-BocCys(Acm)-O-PEG, $n=45$ ), and $\mathrm{HgCl}(t$-Boc-cys-O-PEG). The macromolecular $\mathrm{Mo}$ (VI) complex readily decomposed in water, forming a disulfide derived from the cys-PEG ligands. $\mathrm{MoO}_{2}$ (cys-O$\mathrm{PEG})_{2}$ in water causes the catalytic air oxidation of $\mathrm{PPh}_{3}$ or $\mathrm{P}(\mathrm{OMe})_{3}$. The role of the hydrophobic environment surrounding the active site of molybdenum oxidase was found to protect the $\mathrm{Mo}(\mathrm{VI}) /$ $\mathrm{Mo}(\mathrm{V})$ site from water in bulk. The model dioxo-Mo(VI) complexes are generally insoluble in water thus making it impossible to examine their redox behavior toward biological redox agents.

KEY WORDS Molybdo-oxidase Model / Polymer-Supported Mo(VI)

Complex / Dioxo-di(cysteinyl polyethylene glycol ester)molybdenum(VI) /
\end{abstract}

Dioxomolybdenum(VI) complexes $\left[\mathrm{MoO}_{2} \mathrm{~L}_{2}\right]$ ( $\mathrm{L}=$ bidentate ligand, e.g. chelating $\mathrm{S}-\mathrm{N}$ ligands) are currently attracting interest as models for molybdooxidase, e.g. xanthine oxidase, sulfite oxidase, and aldehyde oxidase. ${ }^{1}$ The oxidation involves $\mathrm{O}$-atom transfer. We made a study of the catalytic activity of $\mathrm{MoO}_{2}$ (cys-OR) $)_{2}$, where $\mathrm{R}=$ methyl, ethyl, isopropyl, and benzyl for the air-oxidation of $\mathrm{PPh}_{3}$ to $\mathrm{Ph}_{3} \mathrm{PO}$ in $\mathrm{DMF} / \mathrm{H}_{2} \mathrm{O}{ }^{2}$ The EPR study of the system, $\mathrm{MoO}_{2}$ (cys-OMe) ${ }_{2} / \mathrm{PPh}_{3}$, indicated that the reduction of the Mo(VI) complex by triphenylphosphine results in the information of a mononuclear $\mathrm{Mo}(\mathrm{V})$ complex. ${ }^{3}$ The presence of a considerable amount of water was found to be an essential factor for the catalytic activity, though the addition of excess water diminished the activity. ${ }^{2}$ Thus the reactivity of dioxo-molybdenum(VI) complexes in the presence of water is important. Isolation of water-soluble cis-dioxoMo(VI) complexes with $(\mathrm{S}, \mathrm{N})$ ligands such as $\mathrm{MoO}_{2}$ (cys) ${ }_{2}{ }^{6}$ is considered to be quite difficult because of their high susceptibility to water. We attempted to synthesize a dioxo-

\footnotetext{
* To whom correspondence should be addressed.
}

Mo(VI) complex with $(\mathrm{S}, \mathrm{N})$ ligands which is soluble in either organic solvents or water to examine the reactivity of the Mo(VI) complex in water. Cys-O-PEG [PEG = poly(ethylene glycol)] was prepared as a water-soluble ( $\mathrm{S}, \mathrm{N})$ ligand. We previously reported the synthesis of $\mathrm{Mo}_{2}{ }^{\mathrm{v}} \mathrm{O}_{2}\left(\mu-\mathrm{O}_{2}\right.$ (cys- NH$\mathrm{PEG})_{2}$ as a model for nitrogenase, ${ }^{4}$ which can be reduced with water-soluble reductants such as $\mathrm{Na}_{2} \mathrm{~S}_{2} \mathrm{O}_{4}$.

This paper describes the syntheses of watersoluble molybdenum(VI) complexes having cysteine thiolato ligands covalently bonded to poly(ethylene glycol). Further, thier redox chemistry in the presence of water at various $\mathrm{pH}$ was examined, and the results are discussed on the basis of the active site structures of molybdo-oxidase.

\section{EXPERIMENTAL}

\section{Materials}

All the solvents were purified by appropriate procedures. $\quad t$-Boc-L-Cys(Acm)-OH $\quad(t-\mathrm{Boc}=t$ butyloxycarbonyl, Acm = acetamidomethyl) was prepared using $t$-Boc-S (Mitsubishi Chem. Co.) 
from Cys(Acm)OH. ${ }^{5}$

\section{Preparation of $t-B o c-C y s($ Acm $)-O-P E G$}

Ten grams of PEG (M.W. 2000, Wako Chem. Co.), $t$-Boc-Cys(Acm)-OH (2.9 g), and dicyclohexyl carbodiimide $(2.1 \mathrm{~g})$ were added to mixed solvents of $\mathrm{CH}_{2} \mathrm{Cl}_{2}(100 \mathrm{ml})$ and ethyl acetate $(70 \mathrm{ml})$. This mixture was stirred at $0^{\circ} \mathrm{C}$ for three hours and at room temperature for three days. The dicyclohexylurea formed was filtered off and the solvents were evaporated in vacuo. The residue was extracted with ethyl acetate to remove dicyclohexylurea. After concentrating the extract to a small volume, the addition of ether resulted in the formation of a solid which was collected, washed with ether and dried in vacuo. An attempt to separate the $t$-Boc-Cys(Acm)O-PEG from the unreacted PEG was unsuccessful. The Cys content in PEG was about $50 \%$ as determined by the intensity ratio of ${ }^{1} \mathrm{H}$ NMR signals at $3.64 \mathrm{ppm}$ due to $\left.{ }^{-} \mathrm{CH}_{2} \mathrm{CH}_{2}-\mathrm{O}\right)_{n}$ and at 1.46 ppm due to $t$-Boc protons.

\section{Preparation of $\mathrm{HCl} \cdot \mathrm{Cys}-\mathrm{O}-\mathrm{PEG}$}

$t$-Boc-Cys(Acm)-O-PEG $(5.0 \mathrm{~g})$ was dissolved in ethyl acetate $(30 \mathrm{ml})$. Hydrogen chloride gas was passed through the solution for $10 \mathrm{~min}$. Ether $(100 \mathrm{ml})$ was added to this solution to precipitate a solid which was collected, washed with ether, and dried in vacuo $(4.2 \mathrm{~g})$. A solution of mercuric chloride in methanol was added to the solution of $\mathrm{HCl} \cdot \mathrm{Cys}(\mathrm{Acm})-\mathrm{O}-\mathrm{PEG}$ in methanol. This mixture was stirred and after $8 \mathrm{~h}$ ether was added to the solution to precipitate a mercury complex which was collected, washed with ether, and dried in vacuo. Hydrogen sulfide was passed through a solution of the mercury complex in methanol with stirring for $30 \mathrm{~min}$ and then the solution was stirred for $2 \mathrm{~h}$. Mercuric sulfide was filtered off and the

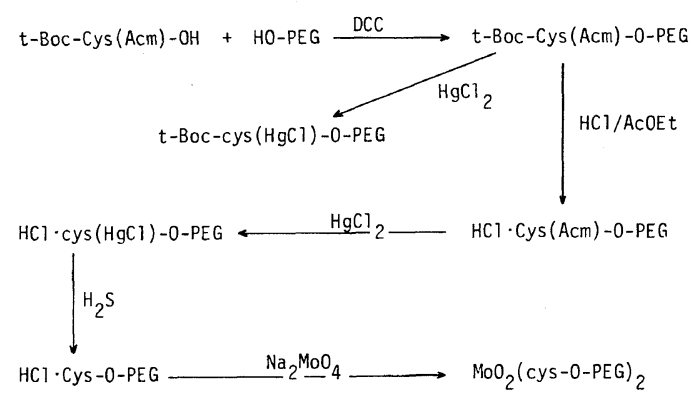

Figure 1. Synthetic scheme of $\mathrm{MoO}_{2}$ (cys-O-PEG) . filtrate was concentrated cautiously in vacuo. The residue was dissolved in a minimum amount of methanol and ether was added to the solution to precipitate a solid which was collected, washed with ether and dried in vacuo $(2.8 \mathrm{~g})$.

\section{Preparation of $\mathrm{HgCl}(\mathrm{t}-\mathrm{Boc}-\mathrm{Cys}-\mathrm{O}-\mathrm{PEG})$}

To a solution of $t$-Boc-Cys(Acm)-O-PEG in methylene chloride/methanol (1:1), $\mathrm{HgCl}_{2}$ was added at room temperature. After the addition of a large amount of water, the methylene chloride layer was collected, washed with water, and concentrated under reduced pressure. A white solid obtained was collected and dired.

\section{Synthesis of $\mathrm{MoO}_{2}$ (cys-O-PEG)}

This was carried out according to Melby's method for $\mathrm{MoO}_{2}$ (cys-OEt) $)_{2}{ }^{7}$ A solution of $\mathrm{Na}_{2} \mathrm{MoO}_{4} \cdot 2 \mathrm{H}_{2} \mathrm{O}(0.22 \mathrm{~g})$ in water was added to an aqueous solution of $\mathrm{HCl}$. Cys-O-PEG (1.g) to give a yellow solution which was extracted with chloroform. The chloroform layer was then dried with anhydrous sodium sulfate. After filtration, ether was added to the filtrate with cooling to precipitate a yellow $\mathrm{Mo}(\mathrm{VI})$ complex. The powder was collected by filtration, washed with ether, and dried in vacuo. Yield $0.8 \mathrm{~g}$.

\section{Physical Measurements}

${ }^{13} \mathrm{C}$ NMR spectra were recorded on a JEOL FX$90 \mathrm{Q}$ spectrometer. CD spectra were obtained on a JASCO J-40A at room temperature. A Raman spectrum was recorded on a JASCO R800 spectrometer using an argon ion laser operated at $488 \mathrm{~nm}$.

\section{RESULTS AND DISCUSSION}

\section{Characterization of $\mathrm{MoO}_{2}$ (cys-O-PEG)}

The ${ }^{13} \mathrm{C}$ NMR spectral technique is highly useful for the analysis of oligopeptides attached to the PEG $-\left(\mathrm{CH}_{2} \mathrm{CH}_{2}-\mathrm{O}\right)_{n}$ sequence since not only methylene carbons of the PEG parts but also those of unreacted PEG give sharp singals centered at $73 \mathrm{ppm}$ in $\mathrm{Me}_{2} \mathrm{SO}-d_{6}$ or in $\mathrm{CDCl}_{3}$. Figure 2 shows the ${ }^{13} \mathrm{C}$ NMR spectra of $t$-Boc-Cys(Acm)-O-PEG, $t$-Boc-cys $(\mathrm{HgCl})$-O-PEG, and $\mathrm{MoO}_{2}$ (cys-O-PEG) ${ }_{2}$. The Cys $\mathrm{C}_{\beta}$ signal of $t$-Boc-Cys(Acm)-O-PEG at $41.9 \mathrm{ppm}$ shifts to $31.5 \mathrm{ppm}$ with the formation of the $\mathrm{Hg}(\mathrm{II})$ complex. Such an upfield shift can be 
a)

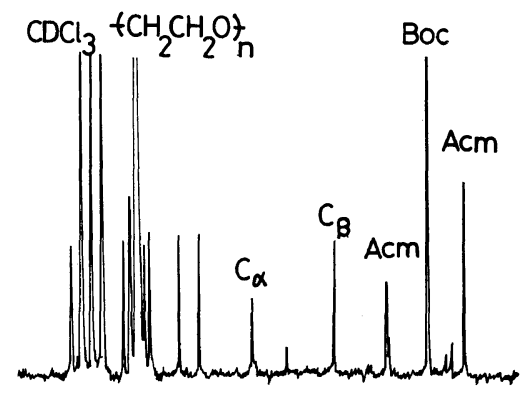

b)
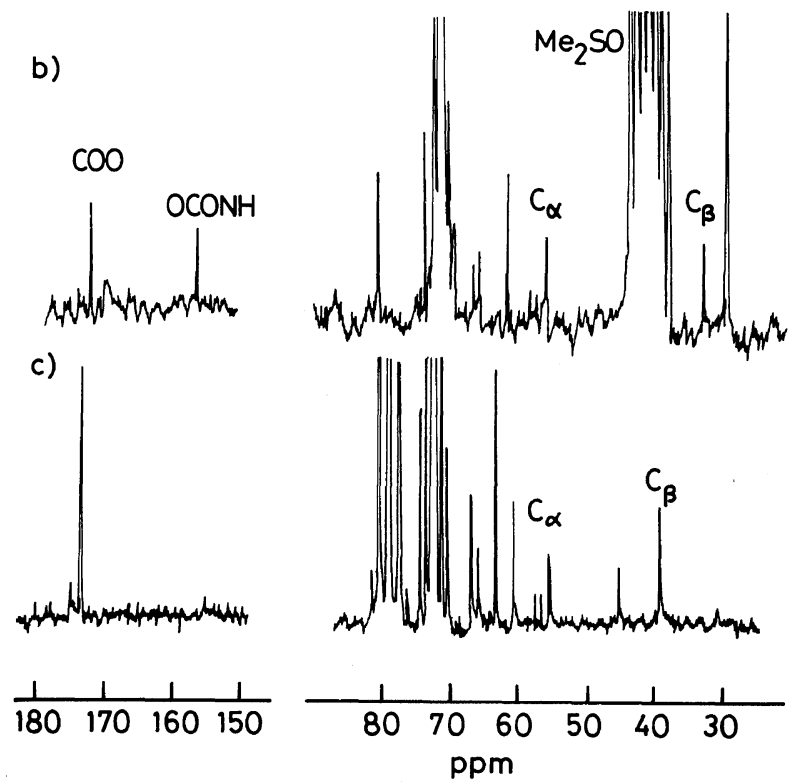

Figure 2. ${ }^{13} \mathrm{C}$ NMR spectra of a) $t$-Boc-Cys(Acm)-O-PEG in $\mathrm{CDCl}_{3}$, b) $\mathrm{HgCl}$ ( $t$-Boc-cys-O-PEG) in $\mathrm{Me}_{2} \mathrm{SO}-d_{6}$, and c) $\mathrm{MoO}_{2}$ (cys-O-PEG) ${ }_{2}$ in $\mathrm{CDCl}_{3}$.

explained as a result of the decrease in the electronegativity of the $\mathrm{C}_{\beta}$ carbon since the electron cloud in the neighboring sulfur flows into the $\mathrm{Hg}$ (II) ion. The observation of the $\mathrm{C}_{\beta}$ signal for $\mathrm{MoO}_{2}-$ (cys-O-PEG) ${ }_{2}$ at $37.7 \mathrm{ppm}$ as in the case of $\mathrm{MoO}_{2}$ (cys-OMe $)_{2}{ }^{8}$ indicates the coordination of the $(\mathrm{S}, \mathrm{N})$ chelate ligands to $\mathrm{Mo}(\mathrm{VI})$ ion as shown in the following structure.

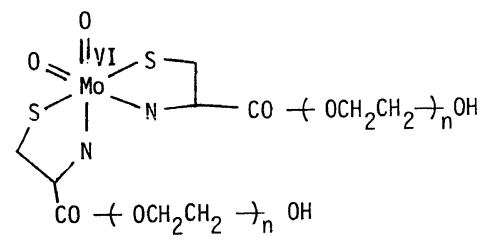

Two absorption maxima were observed for $\mathrm{MoO}_{2}$ (cys-O-PEG) $)_{2}$ at $260 \mathrm{~nm}(\varepsilon, 3500)$ and $350 \mathrm{~nm}$ $(\varepsilon, 2400)$, corresponding to the typical absorptions of $\mathrm{MoO}_{2}$ (cys-OMe $)_{2}$ at $262 \mathrm{~nm}(\varepsilon, 7300)$ and $354 \mathrm{~nm}$ $(\varepsilon, 5400) .^{7}$ The formation of $\mathrm{MoO}_{2}$ (cys-O-PEG) was also supported by comparing its $\mathrm{CD}$ spectra in Figure 3 with those of the authentic sample, $\mathrm{MoO}_{2}$ (cys-OMe $)_{2}$. The differential dichroic absorption $(\Delta \varepsilon,-7.5)$ of $\mathrm{MoO}_{2}$ (cys-O-PEG) $)_{2}$ was about half the value $(\Delta \varepsilon,-16)$ of $\mathrm{MoO}_{2}$ (cys-OMe $)_{2}$ at $290 \mathrm{~nm}$ assignable to the C-T band primarily associated with the Mo-S bond. The $\mathrm{MoO}_{2}$ (cys-OPEG) $)_{2}$ complex showed low stability in DMF and the decrease in $\Delta \varepsilon(-4.7)$ value was observed as shown in Figure 3. However, the $\mathrm{CD}$ shape still retained that of $\mathrm{MoO}_{2}$ (cys-O-PEG) $)_{2}$.

\section{Reaction of $\mathrm{MoO}_{2}$ (cys-O-PEG) ${ }_{2}$ with Water}

The CD spectra of $\mathrm{MoO}_{2}$ (cys-O-PEG) $)_{2}$ in water 


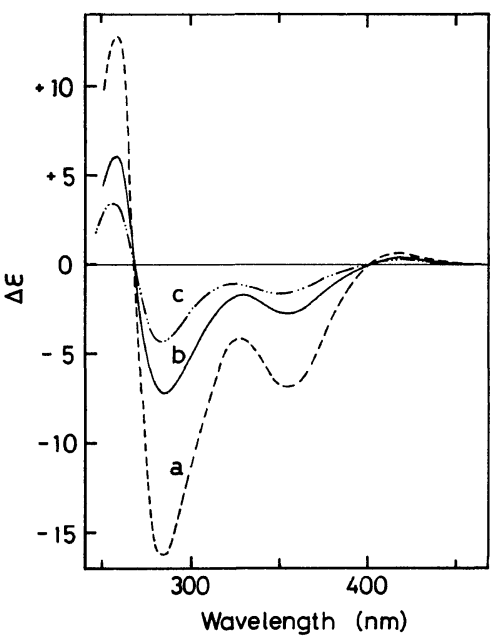

Figure 3. $\mathrm{CD}$ spectra of a) $\mathrm{MoO}_{2}$ (cys-OMe) ${ }_{2}$ in $\mathrm{CHCl}_{3}$, b) $\mathrm{MoO}_{2}$ (cys-O-PEG) $)_{2}$ in $\mathrm{CHCl}_{3}$, and c) $\mathrm{MoO}_{2}$ (cys-O-PEG) ${ }_{2}$ in $\mathrm{DMF} / \mathrm{H}_{2} \mathrm{O}(1: 0.15)$.

indicated a rapid reaction accompanied by an extreme decrease in the $\Delta \varepsilon$ value as shown in Figure 4. The same CD results were obtained when a large amount of water was added to the DMF solution of $\mathrm{MoO}_{2}$ (cys-O-PEG) .

The decrease in the $\Delta \varepsilon$ value means that the species formed by the reaction with water probably have no chiral ligand. Since the synthesis of $\mathrm{MoO}_{2}$ (cys-O-PEG) $)_{2}$ took place in water, the small amount of water contaminated in DMF would not cause such a reaction. Therefore, the above results indicate that the $\mathrm{Mo}=\mathrm{O}$ moiety of $\mathrm{MoO}_{2}$ (cys-OPEG $)_{2}$ is activated in water and oxidizes its own thiolato ligands to form S-S bonds accompanied by a reduction of the Mo species as shown in the following scheme. The formation of a cystine derivative, (cys-O-PEG) ${ }_{2}$, was confirmed by a strong Raman band at $510 \mathrm{~cm}^{-1}$ due to the S-S bonding.

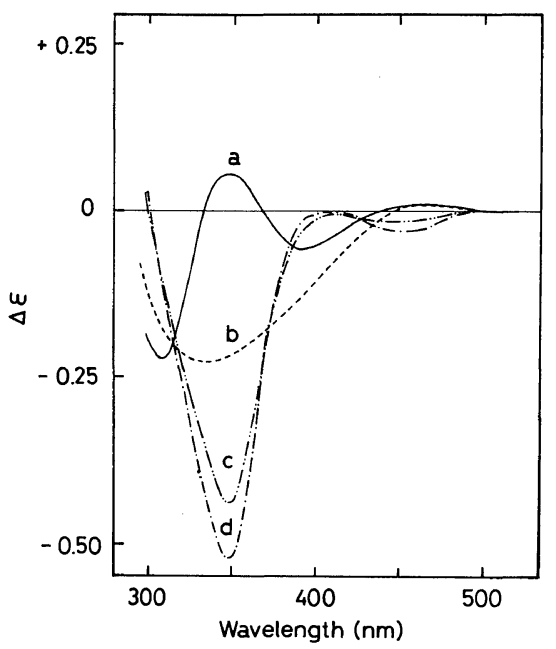

Figure 4. $\mathrm{CD}$ spectra of $\mathrm{MoO}_{2}$ (cys-O-PEG) $)_{2}$ in water under aerobic conditions, a) immediately, b) after $2 \mathrm{~h}, \mathrm{c}$ ) after $15 \mathrm{~h}$, and d) after $24 \mathrm{~h}$.

The formation of cystine by the reaction of $\mathrm{Na}_{2} \mathrm{MoO}_{4}$ with cysteine is well known. ${ }^{10}$ The absorption intensity of $\mathrm{MoO}_{2}$ (cys-O-PEG) when dissolved in water weakened immediately at 374 and $283 \mathrm{~nm}$. The board absorptions at $300 \mathrm{~nm}$ may indicate the formation of $\mathrm{MoO}_{4}{ }^{2-}$ or $\left[\mathrm{Mo}_{2} \mathrm{O}_{2}(\mu\right.$ $\left.\mathrm{O})_{2}\right]^{2+}$. The reduced Mo species gradually give a typical CD pattern of a stable binuclear Mo(V) complex showing a weak trough around $360 \mathrm{~nm}$ $(\Delta \varepsilon,-0.6)$ as observed in the $\mathrm{CD}$ spectrum of $\mathrm{Mo}_{2} \mathrm{O}_{2}(\mu-\mathrm{O})_{2}$ (histidinato) ${ }_{2}$ without the thiolato ligands reported by Suzuki et al. ${ }^{9}$ They also reported that the non-chelating coordination of cystine amino groups to $\mathrm{Mo}_{2} \mathrm{O}_{2}(\mu-\mathrm{O})_{2}{ }^{2-}$ provided a weak $\mathrm{CD}$ extremum. This high reactivity in water suggests that it is difficult to synthesize a dioxo Mo(VI) complex of cysteine in water. The alleged

$$
\text { (nEG }
$$


preparation does not seems plausible, although has been proposed. ${ }^{6}$

The $\mathrm{pH}$ dependence of the $\mathrm{CD}$ spectra of $\mathrm{MoO}_{2}$ (cys-O-PEG) $)_{2}$ was examined. The $\mathrm{Mo}_{2} \mathrm{O}_{2}(\mu$ O) ${ }_{2}{ }^{2+}$ species having bands at $290 \mathrm{~nm}(\Delta \varepsilon,+0.2)$ and $370 \mathrm{~nm}(\Delta \varepsilon,-0.23)$ was formed at $\mathrm{pH} 8.0$. At $\mathrm{pH} 6.0$ and 4.6, only a weak maximum was found over $300 \mathrm{~nm}$. Of course, weak peaks due to the ligand was observed below $250 \mathrm{~nm}$ at low $\mathrm{pH}$.

Reduction of $\mathrm{MoO}_{2}$ (cys-O-PEG $)_{2}$ in $\mathrm{P}(\mathrm{OMe})_{3}$

A mild reduction of $\mathrm{MoO}_{2}$ (cys-O-PEG) $)_{2}$ by trimethylphosphite was studied in water and in DMF/ $\mathrm{H}_{2} \mathrm{O}(1: 0.15)$. Figure 5 shows the $\mathrm{CD}$ spectra of the $\mathrm{Mo}(\mathrm{VI})$ complex with various amounts of $\mathrm{P}(\mathrm{OMe})_{3}$ in $\mathrm{DMF} / \mathrm{H}_{2} \mathrm{O}$ under argon. When the $\mathrm{Mo}(\mathrm{VI})$

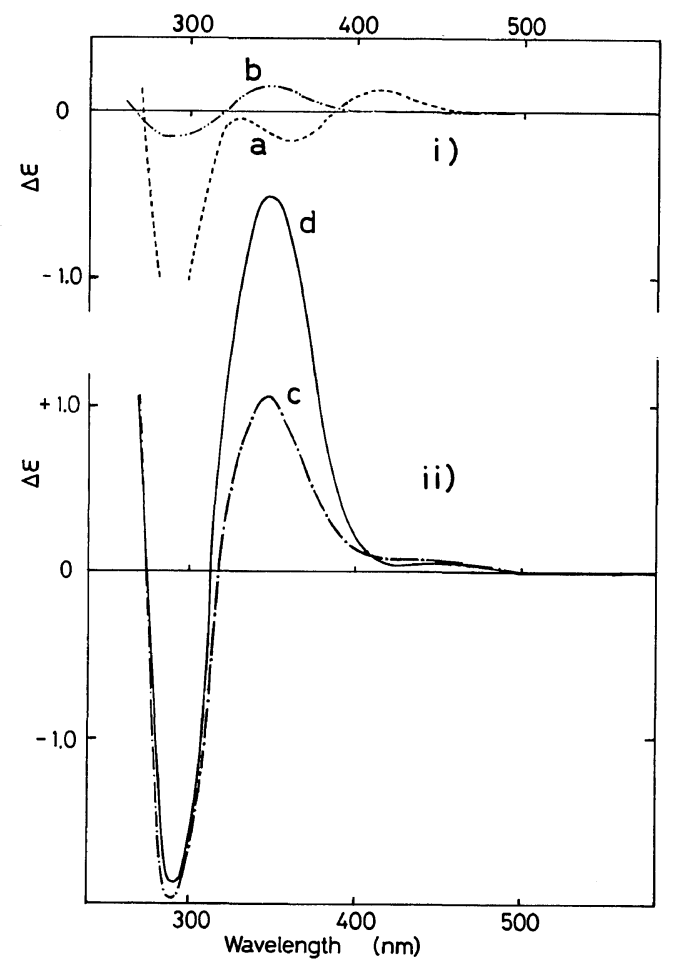

Figure 5. $\mathrm{CD}$ spectra of $\mathrm{MoO}_{2}(\text { cys-O-PEG })_{2}$ in the presence of $\mathrm{P}(\mathrm{OMe})_{3}$ in $\mathrm{DMF} / \mathrm{H}_{2} \mathrm{O} \quad(1: 0.15)$. a) $\mathrm{MoO}_{2}$ (cys-O-PEG) $)_{2}$ without $\mathrm{P}(\mathrm{OMe})_{3}$, b) $\mathrm{P}(\mathrm{OMe})_{3}$ was added to the solution (a) after $17 \mathrm{~h}, \mathrm{c}$ ) the spectrum was obtained immediately after $\mathrm{MoO}_{2}$ (cys-O-PEG) $)_{2}$ was added to the solution of $\mathrm{P}(\mathrm{OMe})_{3}$, and $\mathrm{d}$ ) after $18 \mathrm{~h}$. Conditions: $[\mathrm{Mo}] /\left[\mathrm{P}(\mathrm{OMe})_{3}\right]=1 / 20$ at room temperature. complex was added to the $\mathrm{P}(\mathrm{OMe})_{3} /$ solvent mixture, a miximum at $345 \mathrm{~nm}$ immediately appeared with positive sign as shown in Figure 5-ii-c. The results indicate that the $\mathrm{Mo}(\mathrm{VI})$ complex was reduced smoothly by $\mathrm{P}(\mathrm{OMe})_{3}$ (Figure 5-ii-d) and gave a $\mathrm{Mo}(\mathrm{V})$ species which is probably a mononuclear $\mathrm{Mo}(\mathrm{V})$ complex. On the other hand, the addition of $\mathrm{P}(\mathrm{OMe})_{3}$ to the $\mathrm{DMF} / \mathrm{H}_{2} \mathrm{O}$ solution of $\mathrm{MoO}_{2}$ (cys-PEG) ${ }_{2}$ results in detachment of most of the cysteinate ligands as shown by weak $\mathrm{CD}$ maxima in Figure 5-i-b.

In aqueous solution, the $\mathrm{Mo}(\mathrm{VI})$ complex was reduced rapidly to a $\mathrm{Mo}(\mathrm{V})$ state at $\mathrm{pH}$ 6. The $\mathrm{Mo}(\mathrm{V})$ species was gradually oxidized by air as shown in Figure 6. The weak maxima and shallow troughs of the CD spectrum imply that the decomposition of the complex prevails rather than the reduction to the corresponding $\mathrm{Mo}(\mathrm{V})$ complex. For example, a small maximum at $345 \mathrm{~nm}(\Delta \varepsilon$, $+0.03)$ was observed immediately after the addition of the $\mathrm{Mo}(\mathrm{VI})$ complex to an aqueous solution of $\mathrm{P}(\mathrm{OMe})_{3}$. Thus, even with the addition of a mild reducing reagent, the decomposition of the Mo complex in aqueous solution could not be suppressed. For the air oxidation of $\mathrm{PPh}_{3}$ with $\mathrm{MoO}_{2}$ (cys-OEt) $)_{2}$, a solvent system of $\mathrm{DMF} / \mathrm{H}_{2} \mathrm{O}$

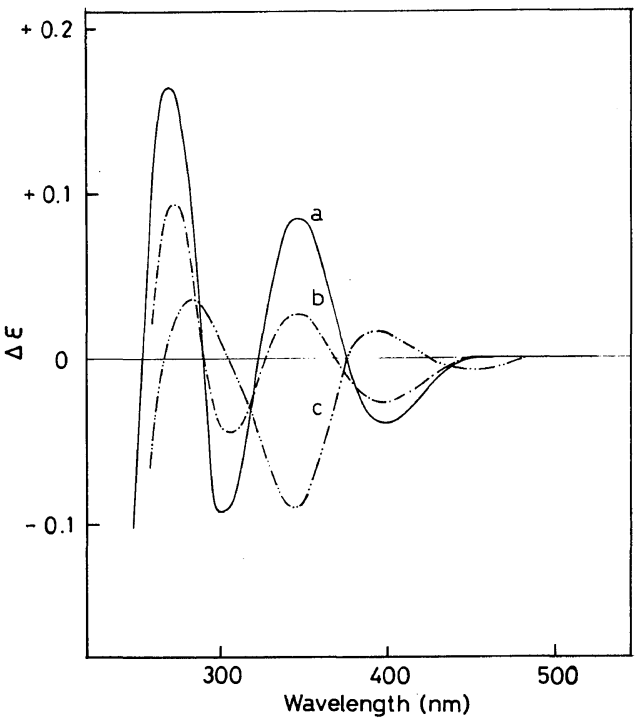

Figure 6. $\mathrm{CD}$ spectra of $\mathrm{MoO}_{2}$ (cys-O-PEG) $)_{2}$ which was added to the solution of $\mathrm{P}(\mathrm{OMe})_{3}$ at $\mathrm{pH} 6.0$ under aerobic conditions, a) immediately, b) after $1 \mathrm{~h}$, and c) after $4 \mathrm{~h}$. 
$(1: 0.15)$ is optimal. ${ }^{2}$ In $\mathrm{DMF} / \mathrm{H}_{2} \mathrm{O}(1: 0.26)$, the catalytic activity decreased to $1 / 2$. This may be due to the partial inactivation of the catalyst. Inactive Mo species may be formed by decomposition of $\mathrm{MoO}_{2}$ (cys-OEt) ${ }_{2} \cdot \mathrm{MoO}_{2}$ (cys-OEt) ${ }_{2}$ is completely insoluble in water and decomposition was not detected. $\mathrm{MoO}_{2}$ (cys-PEG) $)_{2}$ rapidly decomposed when dissolved in water. Therefore, the $\mathrm{MoO}_{2}(\mathrm{~S}, \mathrm{~N})_{2}$ species will be decomposed by a homogeneous reaction with water.

The water content in an aqueous solvent alters the hydrophobic environment surrounding the molybdenum(VI) complex. More than $15 \%$ water may be effective for a hydroxylic reaction at the metal, thereby accelerating the decomposition through redox reaction resulting in S-S bond formation.

\section{Role of the Hydrophobic Environment in the Active Site of Molybdo-enzymes}

The activation of $\mathrm{Mo}=\mathrm{O}$ of the Mo(VI) complex by water suggests that an active site of the native molybdo-enzyme may be associated with water to promote its oxidative ability. The participation of water in the enzymatic oxidation of xanthine oxidase has been discussed by Bray. ${ }^{11}$ However, in the system of catalytic air oxidation of $\mathrm{PPh}_{3}$ by $\mathrm{MoO}_{2}\left(\mathrm{~S}_{2} \mathrm{CNEt}_{2}\right)_{2}$, water is known to be not involved since the formation of a Mo(IV) species proceeds through an oxo-transfer reaction. ${ }^{12,13}$ Stiefel reported that the oxo-transfer could be postulated for the catalytic oxidation of molybdenum oxidase under hydrophobic conditions. ${ }^{14}$ Our EPR study ${ }^{3}$ indicates that a mild reduction of $\mathrm{MoO}_{2}$ (cys$\mathrm{OR})_{2}$ with $\mathrm{PPh}_{3}$ provides a mononuclear $\mathrm{Mo}(\mathrm{V})$ species similar to the $\mathrm{Mo}(\mathrm{V})$ state of xanthine oxidase $^{15}$ or sulfite oxidase. ${ }^{16}$ Therefore, one electron transfer involving water seems to be important for the air oxidation catalyzed by $\mathrm{MoO}_{2}$ (cys-OR) 2 .

As already mentioned, a large excess of water greatly activates $\mathrm{Mo}=\mathrm{O}$ of the $\mathrm{Mo}(\mathrm{VI})$ complexes. The hydrophobic environment surrounding the active sites of molybdenum oxidase ${ }^{14}$ controls contact with the excess water and may possibly contribute to the stability of the chelated Mo(VI) state during the redox cycle.

\section{REFERENCES AND NOTES}

1. E. I. Stiefel in "Molybdenum and MolybdenumContaining Enzymes," M. Coughlan, Ed., Pergamon Press, New York, 1980, p 41.

2. N. Ueyama, M. Yano, H. Miyashita, and A. Nakamura, in preparation.

3. A. Nakamura, N. Ueyama, and M. Kamachi, Chem. Lett., 19 (1981).

4. N. Ueyama, M. Nakata, and A. Nakamura, Kobunshi Ronbunshu, 37, 671 (1980).

5. T. Nagasawa, K. Kuroiwa, K. Narita, and Y. Isowa, Bull. Chem. Soc. Jpn., 46, 1269 (1973).

6. A. Kay and P. C. H. Mitchell, J. Chem. Soc. Sect A, 2421 (1970).

7. L. R. Melby, Inorg. Chem., 8, 349 (1969).

8. ${ }^{13} \mathrm{C}$ NMR spectrum of $\mathrm{MoO}_{2}$ (cys-OMe) ${ }_{2}$ in $\mathrm{Me}_{2} \mathrm{SO}-$ $d_{6}$ provides a signal of cys $C_{\beta}$ at $34 \mathrm{ppm}$ and a signal of cys $C_{\alpha}$ at $62 \mathrm{ppm}$.

9. K. Z. Suzuki, Y. Sasaki, S. Ooi, and K. Saito, Bull. Chem. Soc. Jpn., 53, 1288 (1980).

10. A. Kay and P. C. H. Mitchell, Nature, 219, 267 (1968).

11. R. C. Bray, "Molybdenum and MolybdenumContaining Enzymes," M. Coughlan, Ed., Pergamon Press, New York, 1980.

12. R. Barral, C. Bocard, I. Sereé de Roch, and L. Sajus, Kinet. Catal., 14, 130 (1973).

13. G. J.-J. Chen, J. W. MacDonald, and W. E. Newton, Inorg. Chem., 15, 2612 (1976).

14. E. I. Stiefel, W. E. Newton, G. D. Watt, K. L. Hadfield, and W. A. Bulen, "Bioinorganic Chemistry-II," K. N. Raymond, Ed., The American Chemical Society, Washington, D.C., 1977.

15. R. C. Bray and T. C. Swann, Struct. Bonding, 11, 107 (1972).

16. H. J. Cohen, I. Fridovich, and K. V. Rajagopalan, J. Biol. Chem., 246, 367 (1971). 